\title{
Studies on the Biosynthesis of Rabbit Fibrinogen
}

\author{
By VALDA M. CRADDOCK* AND P. N. CAMPBELL \\ Courtauld Institute of Biochemistry, The Middlesex Hospital Medical School, London, W. 1
}

(Received 14 February 1962)

The attention of this Laboratory has recently been centred on the synthesis of serum albumin by subcellular preparations of rat liver. In considering what other plasma protein synthesized in the liver might be studied in this way, fibrinogen offered many advantages. It was first shown by Miller, Bly \& Bale (1954) that fibrinogen was synthesized in the dog solely in the liver, a finding recently substantiated by Kukral, Kerth, Pancner, Cromer \& Henegar (1961). Moreover, the rate of synthesis of fibrinogen as deduced from its metabolic turnover is probably greater than that of any of the other groups of serum proteins. For example, Cohen, Holloway, Matthews \& McFarlane (1956) estimated that the half-life of fibrinogen in the rabbit is $52-85 \mathrm{hr}$., compared with $190 \mathrm{hr}$. for serum albumin.

From structural considerations fibrinogen is also a protein of much interest. Unlike albumin, which is a globular protein, fibrinogen is a fibrous protein, and the mode of synthesis of the two groups may be different (Gerber \& Altman, 1961). Moreover, in the conversion of fibrinogen into fibrin under the action of thrombin at least two peptides are released, the removal of one of which, designated peptide A, appears to be essential for the subsequent polymerization of fibrin [for review see Laki, Gladner \& Folk (1960)]. Although previous experiments with isotopically labelled amino acids failed to provide definite evidence of the existence of peptides as intermediates in protein synthesis (Campbell, 1958), a protein with the properties of fibrinogen has not previously been studied. Blombäck, Boström \& Vestermark (1960) have shown that the half-life of peptide $B$ in the rabbit is similar to that of fibrin.

It was decided therefore to study the rate of incorporation of an amino acid into the molecule of fibrin and to compare this with the rate of incorporation of the same amino acid into peptide $A$. Blombäck \& Sjöquist (1960) have shown that in the rabbit the single valine residue in peptide $A$ occupies the $N$-terminal position, although this was not known when the present experiments were started. It is also known that the fibrin moiety contains a high proportion of valine residues

* Present address: Toxicology Research Unit, Medical Research Council Laboratories, Carshalton, Surrey.
(Tristram, 1953); so it was decided to inject rabbits with $\left[{ }^{8} \mathrm{H}\right]$ valine and to determine the specific radioactivity of the valine in peptide $A$ and fibrin after a short time-interval. It was hoped thereby to learn something of the metabolic activity of the peptide A compared with that of the rest of the molecule. A preliminary account of this work has appeared (Craddock \& Campbell, 1961).

\section{MATERIALS AND METHODS}

Radioactive amino acids. Uniformly labelled $\mathrm{L}-\left[{ }^{14} \mathrm{C}\right] \mathrm{valine}$ $(100 \mu \mathrm{c} / 1 \cdot 8 \mathrm{mg}$.$) , an acid hydrolysate of { }^{14} \mathrm{C}$-labelled algal protein $\left(100 \mu \mathrm{C} / 2 \cdot 7 \mathrm{mg}\right.$.) and $\mathrm{DL} \cdot\left[{ }^{3} \mathrm{H}\right] \mathrm{valine}(5 \mathrm{mc} / 29 \cdot 25 \mathrm{mg}$. used in Expt. I and $5 \mathrm{mc} / 22 \cdot 13 \mathrm{mg}$. in Expt. II) were obtained from The Radiochemical Centre, Amersham, Bucks.

Injection of animals and isolation of fibrinogen. Rabbits of approx. $3 \mathrm{~kg}$. (body wt.) were injected via a marginal ear vein with $\mathrm{DL}-\left[{ }^{3} \mathrm{H}\right]$ valine dissolved in $0.067 \mathrm{M}$-phosphate buffer, $\mathrm{pH} \mathrm{7 \cdot 3}$. After $20 \mathrm{~min}$. the animals were anaesthetized by injection of phenobarbital sodium, and bled from the inferior vena cava through a silicone-treated tube into a vessel containing sodium oxalate and potassium oxalate. The blood of the two animals was pooled. The plasma was fractionated according to 'Method 6' of Cohn et al. (1946), and the percentage of 'clottable nitrogen' of fraction $I$ was determined by the method of Biggs \& MacFarlane (1957).

Isolation of fibrin and peptide $A$. Fraction I was dissolved in ammonium acetate $(0 \cdot 3 \mathrm{M}, \mathrm{pH} 7 \cdot 0)$ and clotted by the method of Blombäck et al. (1960). The fibrin clot was separated from the supernatant (which was retained), cut up, and washed ten times with water ( $5 \mathrm{ml}$. each time). The washings failed to give a positive reaction with ninhydrin after five operations. The washings were rejected and the fibrin was dried with ethanol.

The clot supernatant was adjusted to $\mathrm{pH} \mathrm{3.0}$ by the addition of $10 \mathrm{~N}$-formic acid, and peptide $\mathrm{A}$ was isolated by chromatography according to the method of Blombäck et al. (1960). In this procedure a column $(0.9 \mathrm{~cm} . \times 30 \mathrm{~cm}$.) of Dowex 50 ( $2 \%$ cross-linked; $200-400$ mesh) is eluted stepwise first with ammonium formate-formic acid buffers, and then with ammonium acetate-acetic acid buffer. Peptide A was detected in the eluent by the method of Lowry, Rosebrough, Farr \& Randall (1951). The peptide solution was desalted by adsorption on a small column of Dowex 50 ( $2 \%$ cross-linked; $\mathrm{H}^{+}$form), and eluted with aq. $2 \mathrm{~N}$ ammonia and evaporated to dryness.

Isolation of valine from fibrin and peptide $A$. The fibrin clot was dried with ethanol and a portion $(65 \mathrm{mg}$.) hydrolysed in a sealed tube with $1.5 \mathrm{ml}$. of $5 \mathrm{~N}-\mathrm{HCl}$ at $110^{\circ}$ for 
$24 \mathrm{hr}$. The humin was removed by centrifuging and the amino acids were separated on a column $(0.9 \mathrm{~cm} . \times 100 \mathrm{~cm}$.) of Zeo-Karb 225 (W.R. 1·5-2.0; $<200$ mesh) according to the method of Hirs, Moore \& Stein (1954), with increasing concentrations of $\mathrm{HCl}$ as eluent. After the emergence of alanine from the column the concentration of $\mathrm{HCl}$ was increased from $1 \mathrm{~N}$ to $2 \mathrm{~N}$. The amino acids in the effluent were located by paper chromatography in butan-1-olacetic acid-water (12:3:5, by vol.). The fractions containing valine were pooled and evaporated to dryness, and the purity of the product was checked by paper chromatography.

Peptide A was hydrolysed and the hydrolysate treated in the same way as for fibrin, except that as the amount of valine present was too small to estimate directly an isotopedilution procedure was used. L-Valine (300 $\mu \mathrm{g}$.) was added as carrier together with $0.5 \mu \mathrm{C}$ of $\mathrm{L}-\left[{ }^{[4} \mathrm{C}\right]$ valine. The specific radioactivity of the valine isolated from the column was determined by plating samples on $2 \mathrm{~cm} .{ }^{2}$ polythene disks and counting under a thin mica end-window GeigerMüller counter at infinite thinness to a standard error of $\pm 3 \%$ or less. The amount of valine on the disks was determined by interaction with ninhydrin according to the method of Cocking \& Yemm (1954). The value obtained was compared with that of a sample of $0.5 \mu \mathrm{C}$ of $\mathrm{L}$-[14 $\mathrm{C}]$ valine plus $300 \mu \mathrm{g}$. of $\mathrm{L}$-valine treated in the same way. The amount of valine originating in the peptide was then calculated.

Determination of the specific radioactivity of $\left[{ }^{8} \mathrm{H}\right]$ valine. Samples of valine (30-300 $\mu$ g.) were 'spotted' on strips of Whatman no. 1 filter paper, so that the total area of the spot did not exceed $2 \mathrm{~cm} .{ }^{2}$. The area of the spot was then cut out and the $\left[{ }^{3} \mathrm{H}\right]$ valine determined by combustion, followed either by reduction with $\mathrm{Zn}$ to $\mathrm{H}_{2}$ gas, or by direct counting of the ${ }^{3} \mathrm{H}_{2} \mathrm{O}$ by liquid-scintillation counting in the Packard Tricarb Automatic Liquid Scintillation spectrometer, by the method of Jacobson, Gupta, Fernandez, Hennix \& Jensen (1960). The counting efficiency was $12.1 \%$ as determined with a standard prepared from ${ }^{3} \mathrm{H}_{2} \mathrm{O}$ obtained from The Radiochemical Centre, Amersham, Bucks.

\section{RESULTS}

Preliminary experiments in which a rabbit was injected with a mixture of ${ }^{14} \mathrm{C}$-labelled amino acids obtained from algal protein showed that the plasma proteins were significantly labelled $20 \mathrm{~min}$. after injection. Since the maximum incorporation into plasma protein in the rabbit is found after about $6 \mathrm{hr}$. (Campbell \& Work, 1952), it was decided to limit the time of incorporation to $20 \mathrm{~min}$. so that any non-uniformity in the distribution of labelled amino acid would be apparent. The results obtained in two experiments are given in Table 1 . The 'clottability' of fraction I was $79 \%$. Contaminating protein was separated from peptide $A$ during its chromatographic isolation, and any protein adhering to the fibrin clot was removed during the repeated washing. By assuming a molecular weight of 350000 for rabbit fibrinogen (Schulman, 1953), and that the peptide $A$ contains one valine residue (Blombäck \& Sjöquist, 1960), the yield of valine
Table 1. Incorporation of $\left[{ }^{3} \mathrm{H}\right]$ valine into fibrinogen in vivo

In each experiment two rabbits were intravenously injected with $\left[{ }^{3} \mathrm{H}\right]$ valine and bled after $20 \mathrm{~min}$. Fibrinogen was isolated from the plasma and clotted with thrombin. Peptide A was isolated from the mixture. The specific radioactivity (counts/min./ $\mu \mathrm{g}$. of amino acid) of the valine obtained both by hydrolysis of peptide $A$ and of the fibrin clot was determined. Each result is the average of at least two determinations.

Dose of $\left[{ }^{3} \mathrm{H}\right]$ valine/rabbit (mc)

Dry wt. of fibrin (mg.)

Amount of valine obtained from peptide A ( $\mu \mathrm{g}$.

Specific activity of peptide valine Specific activity of fibrin valine

$\begin{array}{cc}\text { Expt. I } & \text { Expt. II } \\ 2.5 & 5.0 \\ 230 & 243 \\ 40 & 69 \\ & \\ 64.5 & 74.6 \\ 8.4 & 18.7\end{array}$

originating in the peptide was approx. $50 \%$, similar to that obtained by Blombäck et al. (1960).

In each experiment the specific activity of the peptide valine was considerably higher than that of the valine originating in the fibrin. The difference between the two experiments may be due to the increased specific activity of the valine injected in the second experiment, or to the increased amount of valine administered. In either case more fibrinogen would have been synthesized before the specific radioactivity of the valine fell to a low level.

\section{DISCUSSION}

The results show that the valine incorporated into fibrinogen synthesized in a short timeinterval by the liver in vivo is not uniformly distributed throughout the molecule. The higher specific activity of the peptide valine may be taken as evidence that the $N$-terminal peptide is synthesized separately from the remainder of the molecule, and is turned over at a greater rate. An alternative explanation would be that growth of the fibrinogen chain occurs by the sequential linking of amino acids, terminating in the region of the free amino end of peptide $A$. Then, assuming that partly formed fibrinogen molecules were present at the time of injection, the remaining amino acid sites would be filled with labelled valine, and the higher specific activity of this region would be expected.

With haemoglobin there is evidence that the amino acids are added to the polypeptide chain sequentially, starting at the $N$-terminal end (Bishop, Leahy \& Schweet, 1960) and ending at the free carboxyl end (Dintzis, 1961).

To investigate these two possibilities it would be necessary to know the distribution of $\left[{ }^{3} \mathrm{H}\right]$ valine within the fibrin. Experiments involving characterization of the peptides formed on hydrolysis of tritiated fibrin should give information on this. 


\section{SUMMARY}

1. The distribution of $\left[{ }^{3} \mathrm{H}\right]$ valine in fibrinogen synthesized by the rabbit in a short time-interval in vivo was investigated. The valine located in peptide $A$ was found to have a higher specific activity than that from the remainder of the molecule.

We are grateful to Professor F. Dickens, F.R.S., for his encouragement, Mr H. E. H. Jones for helping with the injections and bleeding, and $\mathrm{Dr} J$. K. Whitehead for gas counting. A grant to the Medical Sohool by the British Empire Cancer Campaign covered the cost of the work.

\section{REFERENCES}

Biggs, R. \& MacFarlane, R. G. (1957). Human Blood Coagulation, p. 412. Oxford: Blackwell Scientific Publications.

Bishop, J., Leahy, J. \& Schweet, R. (1960). Proc. nat. Acad. Sci., Wash., 46, 1030.

Blombäck, B., Boström, H. \& Vestermark, A. (1960). Biochim. biophys. Acta, 38, 502.

Blombäck, B. \& Sjöquist, J. (1960). Acta chem. scand. 14, 493.

Campbell, P. N. (1958). Advanc. Cancer Res. 5, 97.
Campbell, P. N. \& Work, T. S. (1952). Biochem. J. 52, 217. Cocking, E. C. \& Yemm, E. W. (1954). Biochem. J. 58, xii. Cohen, S., Holloway, R. C., Matthews, C. \& MoFarlane, A. S. (1956). Biochem. J. $62,143$.

Cohn, E. J., Strong, L. E., Hughes, W. L., jun., Mulford, D. J., Ashworth, J. N., Melin, M. \& Taylor, H. L. (1946). J. Amer. chem. Soc. 68, 459.

Craddock, V. M. \& Campbell, P. N. (1961). Abstr. Proc. 5th int. Congr. Biochem., Moscow, no. 2, 48,2507.

Dintzis, H. M. (1961). Proc. nat. Acad. Sci., Wash., 47, 247.

Gerber, G. B. \& Altman, K. I. (1961). Nature, Lond., 189, 813.

Hirs, C. H. W., Moore, S. \& Stein, W. H. (1954). J. Amer. chem. Soc. 76, 6063.

Jacobson, H. I., Gupta, G. N., Fernandez, C., Hennix, S. \& Jensen, E. V. (1960). Arch. Biochem. Biophys. 86, 89.

Kukral, J. C., Kerth, J. D., Pancner, R. J., Cromer, D. W. \& Henegar, G. C. (1961). Surg. Gynec. Obstet. 113, 360.

Laki, K., Gladner, J. A. \& Folk, J. E. (1960). Nature, Lond., 187, 758.

Lowry, O. H., Rosebrough, N. J., Farr, A. L. \& Randall, R. J. (1951). J. biol. Chem. 193, 265.

Miller, L. L., Bly, C. G. \& Bale, W. F. (1954). J. exp. Med. 99, 133.

Schulman, S. (1953). J. Amer. chem. Soc. 75, 5846.

Tristram, G. R. (1953). In The Proteins, vol. 1, part A, p. 181. Ed. by Neurath, H. \& Bailey, K. New York: Academic Press Inc.

Biochem. J. (1962) 84, 342

\title{
Studies in the Biochemistry of Micro-organisms
}

\section{PRODUCTION AND BIOSYNTHESIS OF ORSELLINIC ACID BY PENICILLIUM MADRITI G. SMITH*}

\author{
By J. H. BIRKINSHAW AND ANNE GOWLLAND \\ Department of Biochemistry, London School of Hygiene and Tropical Medicine, University of London
}

(Received 6 February 1962)

A study of the metabolism of Penicillium madriti G. Smith led to the isolation from the culture filtrate of two metabolic products, penicillic acid and orsellinic acid. Penicillic acid, a fairly common mould metabolite, was first isolated from Penicillium puberulum Bainier by Alsberg \& Black (1913). Orsellinic acid had not previously been recognized as a fungal product, although Aghoramurthy \& Seshadri (1954) had postulated it as an intermediate in mould metabolism. In view of the work of Birch, Massy-Westropp \& Moye (1955) on 6-methylsalicylic acid, to which orsellinic acid is structurally closely related, acetate coupling seemed the most obvious pathway for biosynthesis, particularly since orsellinic acid, $\mathrm{C}_{8} \mathrm{H}_{8} \mathrm{O}_{4}$, can

* Part 109: Birkinshaw \& Gourlay (1961). theoretically be derived from four acetate units without oxidation or reduction. We have now verified this hypothesis and investigated the possibility of $\mathrm{a}_{4}$ intermediate such as acetoacetic acid in the metabolic pathway between acetate and orsellinic acid. A fuller account of this work is given by Gowlland (1961).

While this investigation was in progress, Mosbach (1959) reported the isolation of orsellinic acid from the culture filtrates of Chaetomium cochliodes Palt. and showed that when supplied with $\mathrm{CH}_{3} \cdot{ }^{14} \mathrm{CO} \cdot{ }^{18} \mathrm{ONa}$ the fungus produced orsellinic acid in which the labelling of both carbon and oxygen atoms conformed to the requirements for a direct condensation of activated acetate units to orsellinic acid (Gatenbeck \& Mosbach, 1959). Later work by Mosbach (1960) has demonstrated 